\title{
Reflection and Reason in Hume and Kant
}

\section{Stephen Engstrom}

In her provocative paper 'Moralism and Cruelty: Reflections on Hume and Kant', Annette Baier compares the different ways in which Humean and Kantian moralities 'pressure people into conformity to the morality in question'. ${ }^{i} \mathrm{Her}$ comparison starts from the idea that these two systems can be seen, respectively, as shame and guilt moralities, with shaming and punishment as the two mechanisms of enforcement. For Humean morality, she claims, mockery and laughter serve that function, whereas Kantian morality maintains itself through commands and punishments. Now a system that relies on commands and punishments is inherently coercive, and Baier's concern, if I understand her, is that such a system, at least in its Kantian version, is prone to moralism and to punishments that are cruel. Cruelty, she points out, is, according to Hume, the worst of the vices. So what is a Humean moral philosopher to do, when confronted with the Kantian position, but to mock it on account of these features? And that is what, at the conclusion of her paper, she represents herself as doing: mocking 'the Kantian moralist', asking 'Why should you be so cruel to yourself?'

In effect, this mockery presses Kantians to confront the question whether their morality can, in Hume's memorable words, 'bear its own survey', that is, whether it can survive the test of reflection that Baier identifies as the Humean standard of authority and normativity. ${ }^{i i}$ The reflection induced by this mockery, it should be noted, lies not so much in the cool exercise of reason as in the workings of sentiment. Mockery calls attention to something related to oneself that is liable to elicit shame. And shame, being unable to bear the survey of its object, seeks where it can to remove or at least to hide the source of embarrassment. So insofar as Kantian moralists are effectively shamed by Baier's mockery, they gain a vivid, first-hand impression of how Kantian morality fares when subjected to the test of reflection.

Baier allows that it 'may be reasonably thought' that she has 'mocked the Kantian position a bit too unmercifully', noting that Kantians are not permitted by their own version of morality to do much mocking back. Acknowledging that 'the true Humean must somehow learn to mock gently', she proposes, as a 


\section{Reflection and Reason in Hume and Kant}

remedy, that 'other Humeans may generously step in to do the job of retorsio iocosa for them'. I do not know whether any generous Humeans have followed up this suggestion, but Baier seems in any case to appreciate that retorts in kind are not likely to be forthcoming from the admirers of Kant she aims to provoke.

In proposing that other Humeans might offer, on behalf of the Kantian, jocular retorts to her mocking of Kant's moral philosophy, Baier signals, by her use of the Latin expression, that she is alluding to a remark that occurs in Kant's discussion of ridicule in the Metaphysics of Morals. Kant classifies ridicule as a vice, but he distinguishes from ridicule what he calls 'jocular retaliation' (retorsio iocosa), which he describes as the rejection of an adversary's offensive, mocking attack by an equal mockery in rightful defence of the respect one person can demand of another. He adds, however, that when the object of mockery is really no object for wit but one in which reason necessarily takes a moral interest, then ... it is better suited to the dignity of the object and respect for humanity to put up either no defence at all against the attack or one conducted with dignity and seriousness' (MS 6:467). On the face of it, this observation would seem to have application in the case at hand, where the object is our understanding of morality itself. If philosophy, and moral philosophy in particular, were an object of idle curiosity or a matter of play and sport, a jocular retort could be appropriate. But where the object touches reason's moral interest, the options are either silence or a dignified, serious defence. It is evidently with this observation in mind that Baier suggests that jocular retorts might not be forthcoming, unless other Humeans generously step in to offer them.

It should not be overlooked, however, that both of the options Kant identifies are presented as ways of responding to an adversary's offensive attack, whereas Baier makes clear that she does not intend her mockery to cross over into vicious ridicule, or something the Kantians she is addressing could reasonably regard as an insulting attack of an adversary. ${ }^{\text {iii }}$ On the contrary, the substance and the tone of Baier's discussion suggest that her mockery may itself be best regarded as a case of retorsio iocosa. So perhaps a good place to begin is with a consideration of what may have triggered it.

We need not look far for an answer. Baier's reaction to Kantian morality appears to reflect, at least in part, an indignation aroused by her view of what the modes of treatment would be by which the guilt morality she attributes to Kant

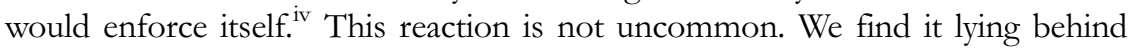
criticisms that others, particularly those with broadly Humean sympathies, have raised against Kantian and other rationalist approaches. ${ }^{\mathrm{v}}$ At the extreme, it is the reaction that Hume says we feel when confronted with instances of angry cruelty: 'All the pity and concern', he says, 'which we have for the miserable sufferers by this vice, turns against the person guilty of it, and produces a stronger hatred than we are sensible of on any other occasion' (T III.iii.3.605-6). Obviously there can 


\section{Stephen Engstrom}

be justice in indignation triggered by cruelty, by the browbeating of pretentious moralism, or even by subtle forms of pressure and intimidation effected through the invocation of reason, morality, or duty.

\section{II}

It is a further question, however, whether the root of the problem traces to the fundamental idea, that morality is based in reason. In its standard usage, 'reason' is an honourific term, and it is a commonplace observation that the very things in life that attract our respect and admiration are, just for that reason, often exploited by those who would turn them to their own advantage. The fact that some people use 'reason', 'rational', or other similar terms to push other people around no more shows there to be anything suspect about reason or the idea that morality is based in reason than displays of attentive solicitude on the part of flatterers and sycophants render suspect the natural human sentiment of sympathy. To the extent that indignation or criticism is in order, it should be directed, not to these natural capacities, but to attempts to exploit the healthy and innocent human response to their normal, appropriate exercise.

These points seem too obvious to be overlooked, so why do those who raise such a criticism find it to be an objection to a conception of morality as based in reason that the name of reason can be, and often is, used in the way I just described? Hume argues resourcefully that sympathy and self-interest can limit and regulate themselves in order to render themselves consistent with themselves. We might thus expect that, by parity, Baier and other admirers of Hume would be open to the possibility that reason furnishes a standard for its own employment, whereby attempts to use reason in ways that involve the mistreatment of others are in conflict with themselves and constitute abuses of reason that are subject to criticism and correction by that same standard.

If Humeans leave this possibility unexplored, they presumably do so at least in part because they are antecedently persuaded that reason is not capable of serving as a standard that could regulate its own employment in moral judgement. Hume famously maintains that although reason enables the intelligent pursuit of the objects of our passions, it provides no standard or principle for the assessment of those objects themselves with respect to their suitability for incorporation into the ends of conduct. Nor, he adds, could reason alone have any influence upon the will even if it could furnish such a standard. Reason is cool and detached, indeed 'perfectly inert', and as such is suited to no practical function other than one of serving and obeying the passions (T III.i.1.457-58; II.iii.3.415). ${ }^{\mathrm{vi}}$

How then do philosophers come mistakenly to think that reason has a practical influence? Hume explains that included among our desires are certain 


\section{Reflection and Reason in Hume and Kant}

calmer passions, such as 'the general appetite to good', which may, owing to their tranquility, be confused with reason; those who fail to examine these objects with 'a strict philosophic eye' are therefore liable to presume that reason gives us some insight into the proper ends of conduct ( $T$ II.iii.3.417). And if power brings security and with it a general calming of the passions (a big 'if', perhaps), those who occupy positions of power may be especially prone to the confusion. Thus the name of reason may come to be invoked, with some degree of sincerity, by members of a dominant social group — including philosophers, if their eye is not strict — who, seeking to maintain their position, impose on others their favoured conception of the good; in their hands, the name of reason becomes an instrument for controlling the thought and conduct of others.

It is understandable, then, how those who share such Humean convictions would be ready to view with suspicion a philosophical account of morality as founded in reason. From this Humean point of view, such an account will at best seem to rest on confusion of the calm passions with a supposed operation of a power of rational insight capable of moving us to act accordingly. And at worst it will seem to reflect a presumptuous, insidious attempt to impose a particular moral outlook and code, perhaps as a form of social control. Suspicion may thus fall on the entire Kantian approach, particularly in view of the prominent place it gives to laws, commands, and imperatives.

Baier's dissatisfaction with Kant's account of morality seems to fit this description, and it seems in particular to derive from her idea that a certain arrogant, alienating individualism infuses the rationalism to which she sees Kant as subscribing. In this respect too she has company, even among thinkers who do not share her Humean naturalism. Figures as diverse as Luther, Rousseau, and Iris Murdoch have inveighed against proud, Promethean reason and its sulfurous light. To the extent that Baier's dissatisfaction has such a focus, it may be the Kantian ideal of autonomy that is above all the object of her mockery. In addition to associating this ideal with arrogant individualism, Baier sees it as masculine in character. At one point, for instance, after suggesting that Kant did not intend autonomy for women, but 'only for first-class, really rational, persons', she relates this ideal to 'the male fixation on the special skill of drafting legislation', 'the bureaucratic mentality of rule worship', and 'the male exaggeration of the importance of independence over mutual interdependence'. vii

With these considerations in mind, we are in a position to describe how Baier's mocking question 'Why should you be so cruel to yourself?' pressures such a Kantian into the test of reflection. The cruelty to which it refers is associated with moralism, and in particular with a male presumption of superior moral-rational enlightenment. Such moralistic cruelty, whether inflicted on another or on oneself, exhibits, in its anger and in the excessive harshness of its punishments, a kind of frustration, evincing thereby the ostensibly 
autonomous master's implicit awareness of the lack of power that his conceited notions of what is right and what is good have in their own right to determine others' thought and conduct or even his own. ${ }^{\text {viii }}$ By exposing to the light of day such cruelty and the weakness it discloses, mockery elicits shame, as the proud man is confronted with the failure on the part of what he presumes to be his rational insight into what is right and what is good to have the cognitive power to convince others or even himself of its own validity.

\section{III}

It is a further question, however, whether this shame touches reason itself, whether it exposes something mortifying in the very capacity, revealing that reason - pure, autonomous reason - cannot bear its own survey, or whether on the contrary it might be through an implicit comparison of its object with a standard of reason that such shame first arises. At first glance, this question might seem odd. We are familiar with the idea that a healthy psyche in an individual human being should be able to contemplate itself without uneasiness or distress, but it may seem less clear what the test of reflection might come to in the case of reason itself. So let me briefly fill in some context, relating the issue to Baier's reading of Hume.

Baier argues that Hume shifts the source of authority, or of normativity, from sovereign deductive reason, the rationalists' favoured candidate, to reflection. ${ }^{\text {ix }}$ She notes that Leibniz and other rationalists had assigned the power of reflection to reason, but she claims that Hume, while accepting that reflection is the standard of authority for human norms, 'generalizes' the reflective operation, thereby opening up space for an argument that the passions including the habits of the imagination and the moral sentiment - have a better claim than does deductive reason to being 'reflective faculties', that is, faculties that are 'capable of being turned on themselves without incoherence or selfcondemnation'. By this route, Baier suggests, Hume arrives at the idea that what ultimately gives authority to a given mental habit or nexus of habits is its capacity, when considered not only by itself but also as a strand of the broader psychic and social fabric, to survive the test of reflection carried out in the most authoritative survey, that of the whole self-surveying mind of the representative of the party of humankind, concerned for its well-being. On Baier's reading of Hume's Treatise of Human Nature, the whole sweep of its argument is directed to showing that pure reason cannot bear its own survey, and that it is only when reflection is exercised by the passions, under the guidance of the moral sentiment, as reason is rehabilitated in a subservient relation to them within the mental economy, that stability can be secured, both in the individual and in society. 


\section{Reflection and Reason in Hume and Kant}

According to Baier, then, Hume applies the test of reflection not merely to reason in its practical application, but even to deductive, scientific reason, and in doing so employs a generalized conception of a reflective operation, asking whether reason can be turned on itself 'without incoherence or selfcondemnation'. So the natural place to begin, it would seem, would be with a consideration of the sceptical arguments regarding demonstrative reason that Hume sets out in the first book of the Treatise, where it does appear that reason is being turned on itself. Here, however, we encounter a complication. For on inspection these arguments turn out to be constructed in a way that prevents them from being directed against reason as Kant understands it. They assume a conception of reason that implicitly relies on a commitment to 'the experimental Method of Reasoning' on which Hume founds his science of human nature ( $T$ xi, $\mathrm{xvi}$ ), whereas Kant does not subscribe to this experimental program. Since following this method is a matter of 'deducing general maxims from a comparison of particular instances' (ECPM 174), Hume must deduce the general propositions that make up his account of reason from a comparison of actual judgements that constitute particular bits of reasoning. It is accordingly not open to him to develop an account in the way that Kant does, from the selfconsciousness that figures in reason's activity. ${ }^{\mathrm{x}}$ In a word, Hume must acquire his basic idea of reason through its use rather than in its use. Because conflicts may be discovered among the actual judgements compared, Hume's experimental method cannot ensure that the conception of reason arrived at through such comparison is free of the thought of a liability to err, even though such a liability, being contingently known, is not already thought in the basic concept.

Thus, in the initial characterization of demonstrative reasoning that he offers at the outset of his sceptical arguments, Hume describes the faculties employed in such reasoning as 'fallible and uncertain'. Reason so conceived must regard its own judgements as suspect until proven sound, rather than as sound until proven suspect, and so must prescribe for its own use the maxim that its every judgement must be reviewed in a new judgment: 'We must, therefore, in every reasoning form a new judgment, as a check or controul on our first judgment' (T I.iv.1.180). The stage is thereby set for a sceptic to turn reason's own maxims against it, humiliating reason 'by making use of rational arguments that prove the fallaciousness and imbecility of reason' ( $T$ 186). In effect, Hume presents a sceptical attack on dogmatic reason, and since his experimental method blocks access to a conception of reason that, by not building in from the start a contingently known liability to err, would leave intact the possibility of effective self-regulation, he has no recourse but to note with relief that 'nature breaks the force of all sceptical arguments in time', saving human reason from being 'totally destroy'd' ( $T$ 187).

It appears, then, that Kant's conception of reason contains less than Hume's does in one significant respect, in that it does not include already at the ground 
level a thought of fallibility, deduced from experience. (This is not to say that this thought is excluded, but only that it is not built in from the start.) In another respect, however, Kant's conception contains, not less than Hume's, but more. This second difference, like the first, will prove to be relevant to the question whether reason as Kant conceives of it can bear its own survey, whether it can be turned on itself 'without incoherence or self-condemnation'. To bring this further difference into view, it will be helpful to begin with a brief description of the Humean conception.

Hume appreciates that reason, according to our ordinary understanding of it, bears a relation to truth and knowledge. Notwithstanding the fallibility he ascribes to it, he acknowledges that 'Our reason must be consider'd as a kind of cause, of which truth is the natural effect' ( $T$ I.iv.1.180). And in its a priori (or scientific) use, where reason 'is nothing but the comparing of ideas', knowledge (or science) - 'the assurance arising from the comparison of ideas' - can be attained (T III.i.1.466; I.iii.9.124). Relying on such comparisons alone, reason can derive, with demonstrative certainty, conclusions from given principles or premises. Knowledge arising from the comparison of ideas, however, is always a discovery of relations dependent on the ideas compared, so a priori reasoning cannot establish any proposition whose truth is connected specifically with relations among the things its ideas represent. The confinement to such comparison also implies that 'reason alone can never give rise to any original idea' ( $T$ I.iii.14.157). In short, Hume accepts the traditional conception of human reason as discursive - as a capacity to know on the basis of relations among ideas in judgements and on the basis of relations among judgements in reasoning - but he denies that reason is or has access to a power of insight that could intuit a substantive first principle or the essences of things.

Kant's view of reason can be described in broadly similar terms ( $\mathrm{rr} V \mathrm{~A} 298$ 305/B355-61). He too conceives of human reason as a capacity by which we gain a priori knowledge on the basis of relations among concepts in judgements and on the basis of relations among judgements in conclusions derived from principles or premises, and he too denies that we have a power of rational or intellectual intuition. So both Hume and Kant conceive of human reason as wholly discursive; neither countenances the rational intuitions of, say, Cartesian epistemology. But there is also a noteworthy difference. On Hume's conception of it, this discursive capacity lacks any spontaneous power of combination. The basic power of the mind to unite its ideas is vested solely in the imagination, operating in conjunction with the passions. Hume does not investigate the possibility that reason's discursive activity might be originally synthetic in nature. Nor is he alone in leaving this possibility unexplored. Working out the idea of a synthetically discursive cognitive capacity requires a fundamental rethinking of a standard philosophical conception of human 


\section{Reflection and Reason in Hume and Kant}

knowledge and how it is related to its object and to its subject. This is not the place to canvass the particulars of Kant's reconception, among which are included his 'Copernican' way of thinking and his distinction between appearances and things in themselves. It will suffice for present purposes if we can explain in general terms how this richer conception of reason arises by indicating how it is rooted in our ordinary, prephilosophical understanding of discursive knowledge. To this end, I will mention two closely related points, which are implicit in that understanding and which, taken together, implicate the idea of a spontaneous power of combination.

First, it is part of that ordinary understanding of such knowledge that it is self-conscious in character. Self-consciousness is present, at least implicitly, in all thinking, and it constitutes the identity of the thinking subject's conscious activity. This is the identity that Hume failed to find when, as required by his principle that all ideas arise, directly or indirectly, from impressions they resemble, ${ }^{\mathrm{xi}}$ he searched for the impression from which the idea of self might be derived: 'when I enter most intimately into what I call myself', he famously reported, 'I always stumble on some particular perception or other, of heat or cold, light or shade, love or hatred, pain or pleasure. I never can catch myself at any time without a perception, and never can observe any thing but the perception' ( $T$ I.iv.6.252). This outcome was preordained, because Hume attended only to the impressions, which are all constituted by the differences in sensation or feeling by which one such perception can be distinguished from another. He thereby neglected the identical activity of consciousness itself, across that diversity of perception, an identity that can never be found in any impression.

This identical activity, which can be recognized only in self-consciousness, is the ground activity of the thinking subject, to which all of its activities belong and in virtue of which they are all self-consciously constituted, even in those respects in which they are distinguished from one another. Consider, for instance, the difference between judging and mere thinking. In judging that things are thus and so, I understand, at least implicitly, that I am judging, not merely thinking. A judgement figuring in discursive knowledge consists in affirmation (or denial), which is constituted by an awareness of itself as more than a mere supposition or a mere entertaining of a thought. Hume speaks here of a difference in feeling. 'An idea assented to', he says, 'feels different from a fictitious idea, that the fancy alone presents to us' (T 629; cf. 636 and I.iii.7). But Kant directs our attention to differences in self-determining acts, which are constituted by the thinking subject's understanding of those differences, not by differences in the ways in which the mind feels itself to be affected. His focus on self-determining acts is registered in his well-known characterization of the intellect in terms of spontaneity ( $K r V$ A50-51/B74-75).

It is of crucial importance not to misconceive the self-consciousness to which Kant means to direct our attention. We are exposed to a particular danger 
of misconception here when comparing the self-consciousness of which Kant speaks with the reflection that Hume, on Baier's reading of him, takes to be the source of authority, a danger that is heightened by the fact that in contexts where Kant is thinking of self-consciousness he too will sometimes speak of reflection. The chief point to hold firmly in mind is that, for Kant, self-consciousness is immediate, though it may be merely implicit. He will use 'reflection' (Reflexion, Überlegung) to refer to the self-conscious activity through which self-consciousness itself becomes explicit. When for instance I come to recognize, through reflection, that the fir, the willow, and the linden that I perceive before me fall 'under' a common representation - say, the concept tree - my reflection brings to explicit consciousness the identity of an act of conscious representing that was implicitly present all along in each of my perceptions, notwithstanding the differences between them, so that now, for the first time, I am conscious of a representation they share in common as the identical representation it is. ${ }^{\text {xii }}$ Similarly, in recognizing that the moon is round, I can, through reflection, gain explicit consciousness of the use of the subjectpredicate relation that has all along implicitly informed my employment, in that same recognition, of the concepts it contains. And in the assertion of one judgement on the basis of another, reflection can likewise enable explicit consciousness of that same act, in which conclusion is related to premise.

Because reflection in Kant's sense is related to self-consciousness in the manner just described, it is not well characterized as a 'stepping back' to gain 'reflective distance', as if we needed to move to a different place to gain perspective on ourselves, or to bring ourselves or our activity into view. Such expressions do of course have their proper use, for instance in descriptions of how, in situations that occasion uncertainty or doubt, we may withdraw from some activity in which we were absorbed, calling it into question; but they do not square well with the immediacy of self-consciousness, the identity of self-consciousness with the consciousness of which it is a consciousness. For similar reasons, it would not be suitable to model reflection in Kant's sense on the sort of reflection induced by mockery or shaming, or to characterize it in the terms Baier uses to describe Hume's 'generalized' reflection, as the turning of a mental faculty or operation on itself, the bringing of it under its own survey. When the reflective operation is described in this way, once again immediacy is lost. Such a description carries the implicit suggestion that the faculty or operation in question is naturally or in the first instance directed to objects other than itself but can somehow, in a special use, 'a reflex act', be applied to itself, or made to take itself as an object. Yet even in this special self-application, there is still a difference between the object and the belief or sentiment that arises through the reflection. For Hume, reflection is always by way of ideas, and ideas, along with the passions and sentiments that may arise from them, are always 


\section{Reflection and Reason in Hume and Kant}

distinct from the perceptions from which they derive and which, like a mirror, they 'reflect', or represent (T I.i.2.7-8; cf. ECHU II.17-18). Even in the reflective operation of a capacity that, like the moral sense, can 'bear its own survey', Hume will distinguish the sentiment an idea represents from the sentiment to which it gives rise, as he does in his famous claim that 'the first virtuous motive, which bestows a merit on any action, can never be a regard to the virtue of that action' ( $T$ III.ii.1.478). Rather than providing a suitable characterization of how explicit self-consciousness arises, Baier's description of reflection as the turning of a mental faculty or operation on itself takes for granted that the distinction between self and that which is other than self is already understood. Reflection in Kant's sense is better regarded as a specific type of contemplation, or attention, through which, in the activity of conscious representing, we become explicitly conscious of that activity itself and its identity, notwithstanding the diversity of representation in which it figures.

I turn now to the second point, that discursive knowledge has unity. This point, as I said, is closely related to the first and is similarly implicit in our ordinary understanding of knowledge. ${ }^{\text {xii }}$ The unity of knowledge entails, first, that knowledge never conflicts with knowledge. If we encounter conflict among our judgements, one of them must be erroneous. The unity of knowledge also entails, positively, that knowledge must agree with knowledge. This unity has two aspects, one reflecting cognition's relation to objects, the other its relation to subjects. On the objective side, the unity of knowledge implies an agreement among cognitions so far as they differ in content, or in the objects they represent. This is the familiar agreement that constitutes coherence among judgements, the coherence in virtue of which they are suited to stand together in a single body of knowledge, in which objects are represented as belonging to a law-governed system. On the subjective side, the unity of knowledge implies an agreement among cognitions so far as they differ, not in content, but in respect of judging subjects, in that insofar as a given subject's judgement constitutes knowledge, it follows that other subjects will be able to agree with that judgement, provided that their cognitive capacity and its exercise are not impeded and that they are able to gain acquaintance with the object in question. Both aspects of unity are utterly familiar, and both are recognized by Hume, though he does not consider the possibility that they are already implicated in our understanding of knowledge.

Implicit in our ordinary understanding of discursive knowledge, then, we find not only an awareness that such knowledge is self-conscious, but also a recognition that it has unity. If we now consider these two points together, we can see that the unity of knowledge, in both of its aspects, is recognized in cognition's self-consciousness, a priori. It is not by empirical discovery that we understand that coherence is a mark of knowledge and truth, or that knowledge possessed by 
one subject must also be, in principle, available to other subjects, other bearers of the cognitive capacity. And once we see that the unity of knowledge is recognized in self-consciousness, we can also see, first, that this unity, rather than being grounded in anything lying outside knowledge and its own self-understanding, must originate in the cognitive capacity we share in common; second, that self-consciousness, rather than being grounded in the individual subject alone, must likewise originate in that same common capacity; and therefore, third, that the original $I$ of self-consciousness and the origin of cognition's unity are the same, being nothing but the cognitive capacity itself. Although the exercise of this capacity depends on external, sensible conditions, without which the representational materials requisite for knowledge would be lacking, it is nevertheless our capacity for discursive knowledge itself that secures, in its exercise, the unity of those materials, thereby constituting knowledge. Kant gives expression to this insight when, in the transcendental deduction of the categories in the Critique of Pure Reason, he characterizes our self-conscious cognitive capacity as a faculty of combination or synthesis (KrV B134-35, B145).

I have been discussing the self-consciously unified character of discursive knowledge with a view to considering whether pure reason, as Kant conceives of it, meets the standard of authority that Baier sees Hume as employing, the test of reflection expressed in the question whether reason can bear its own survey. We are now in a position to say that if, as Kant holds, pure reason's a priori discursive knowledge is nothing other than the basic, self-consciously exercised requirement of unity that constitutes our cognitive capacity as a faculty of synthesis, then there seems to be no way of understanding this question on which the answer would not be 'yes'. There is no possibility that the condition and source of unity itself and of its very idea might be conscious of itself as in conflict with itself. ${ }^{\mathrm{xv}}$ Indeed, the question seems a little off the mark, as applied to reason. For, as I noted, to ask whether a power can bear its own survey is implicitly to suggest that the power is in the first instance directed to something other than itself, yet may, in a special reflective operation, be turned on itself. Reason, however, as the power of the cognitive faculty to secure the unity of its own self-conscious exercise, is an essentially self-directed power. 'Pure reason', Kant says, 'is in fact concerned with nothing but itself' (KrV A680/B708).

\section{IV}

But what about the Kantian ideal of autonomy? What about the arrogant individualism that seems to be above all the object of Baier's criticism? As I will now try to explain, the points we have just noted about Kant's conception of reason and about the way in which that conception is related to our ordinary 


\section{Reflection and Reason in Hume and Kant}

understanding of discursive knowledge have a bearing on these questions. Hume, as we know, rejects the possibility of a practical application of reason, famously claiming to have proved that 'reason is perfectly inert' ( $T$ III.i.1.458). But since Kant's conception of reason derives from reflection on our ordinary understanding of discursive knowledge as a self-conscious synthetic activity, reason as he conceives of it does not lie merely in 'the comparing of ideas', but stands in an active, productive relation to knowledge, as the source of its cognition-constituting unity. His conception is thus open, in a way that Hume's is not, to accommodating the idea that reason has a practical as well as a theoretical use - an idea that, as I will now argue, already informs our thinking in everyday practical life.

In our ordinary practical thought, we understand ourselves to be capable of effectively determining how we should live and what we should do, and in the practical judgements in which we make these determinations, and in which we thereby determine our wills, we take ourselves, in a wide range of normal cases, to know what we should do. As more-or-less decently brought-up adults, we suppose that (as we commonly put it) we know right from wrong. We accordingly understand our judgements about what we should do to be subject to both aspects of the cognitive condition of unity that I described earlier in connection with the theoretical use of discursive reason. We recognize, first, that judgements concerning different cases must nevertheless cohere with one another, that where cases do not differ in a way that bears on our judgements, what is right or good for me to do is right or good for you to do as well. Second, although our practical thought is in the first instance engaged in directing our own individual conduct, we suppose that different persons, if properly and unconstrainedly exercising their capacities to make judgements of this sort, will in suitable conditions be able to agree about what each should or should not do. We turn to one another for advice, and it matters to us in an immediate way whether others agree or disagree with us. This concern that our judgements be seconded by others is one that Baier and Hume rightly stress, but it flows directly from the discursivity of practical reason and registers an original interdependence among persons, counter to 'the male exaggeration of the importance of independence' that Baier criticizes.

These two conditions of unity, each recognized in ordinary practical thought and each constituting a requirement of reason in its practical employment, are highlighted at once in Kant's third formulation of the categorical imperative, the formula of autonomy, which requires that our practical judgements be suitable for inclusion in a system of practical laws that could govern all persons through being laws with which all persons could freely agree ( $G$ 4:431-33). What is crucial to appreciate here is that the autonomy expressed in this requirement is precisely opposed to the individualism that Baier understandably deplores. Autonomy is 
self-rule, but not the self-rule of an isolated rational individual. The autonomy invoked is the autonomy of practical reason, not what is nowadays usually understood under the rubric 'personal autonomy'. Reason is the common discursive cognitive power that we all share as persons, and practical reason is a use of that same power, the use in which, by determining, in accordance with reason's conditions of unity, what we should do, we can move ourselves to do what we should do. It cannot possibly divide us; it can only unite us, as equals, under law.

When the rational man, proud of his personal autonomy, is effectively shamed, the humiliation he suffers rests in his painful awareness that his moralistic presumption of moral-rational superiority over others can never be squared with his deeper self-understanding, which begins in his practical selfconsciousness and the implicit recognition it contains of the requirement of unity and agreement that constitutes the common reason he shares with all others. His self-conception of individual rational superiority can never bear its own survey, because it conflicts with this requirement of reason that it itself implicitly purports to satisfy. Such a man's self-conception thus fails to meet the test of reflection that constitutes the Humean standard of authority, but this failure derives from its failure to meet a deeper standard, recognized in a different form of reflection and residing in a deeper conception of self, which Hume's experimental method prevents him from considering. Kant describes this experience of shame in his well-known account of respect as a feeling that arises through the humiliation of an individual's self-conceit by reason's moral law. Such shame is distinctively ethical, differing from other varieties on account of its specific dependence on this deeper, rational self-consciousness, the selfconsciousness of pure practical reason.

\section{V}

I close with a word about guilt and punishment, and Baier's assimilation of Hume's and Kant's systems to moralities of shame and of guilt. As the foregoing mention of Kant's account of respect may already remind us, this assimilation needs to be qualified, at least with regard to Kant. In Kant's system the distinction between guilt and shame lines up with the broad division of his doctrine of morals into the juridical and the ethical domains, or what he calls the doctrine of right and the doctrine of virtue. In ethics, practical reason enforces its requirements solely through the feeling of shame and humiliation, along the lines I just sketched, and not at all through guilt and punishment. ${ }^{\text {xvi }}$ The reason for this is straightforward. By its very nature, the machinery of guilt and punishment is incapable of contributing in any positive way to morality and virtue, which pertain to persons' inner dispositions and ends. It contributes rather to legality, or 
the conformity of outer actions to law. Enforcement through guilt and punishment is accordingly confined to the legal sphere of external freedom, where the law of reason can be determined and coercively enforced by a publicly established regime of legal and political institutions.

Kant's discussion of punishment, particularly his endorsement of the ius talionis, receives a good deal of critical attention in Baier's paper. I will not take up the issue of punishment here, except to remark that the fundamental principle on which Kant's thinking about punishment relies — what he calls 'the principle of equality' - is, I believe, indisputable if we understand it, as he does, according to its spirit, even though our judgements may differ, and may differ from his, over how it is to be applied in difficult cases. In fact, Baier's own mocking retort to the moralizing Kantian male depends on this principle - the idea, roughly, that, among persons, originally equal under the law, where one has wronged another, introducing an inequality, it is right that something equal be returned, to restore the equality. This principle applies just as much where the wronging lies in arrogant disparagement as where it lies in arrogating action. ${ }^{\text {xvii }}$

That brings us back to mocking retorts. If Baier was hoping that the response to 'Moralism and Cruelty' that she said she was anticipating from admirers of Kant would come in the form of such a retort - a jocular retaliation to her possibly too unmerciful mockery — then she would have been disappointed with these reflections. They deliver no such equalizing repayment in kind, and they are anything but jocular, containing nothing to match the playful, incisive wit that enlivens her insightful and imaginative comparison of the two systems. But it is hardly likely that she seriously expected any such thing, whether from Kantians or from generous Humeans on their behalf. Her real hope, I believe, was to prompt her readers to join her in a reflective comparison of the two moralities, and that is what I have begun to do here. ${ }^{\text {xviii }}$

\title{
Stephen Engstrom \\ University of Pittsburgh engstrom@pitt.edu
}

\author{
Abbreviations \\ Hume \\ ECHU An Enquiry Concerning Human Understanding (Hume 1975) \\ ECPM An Enquiry Concerning the Principles of Morals (Hume 1975) \\ T A Treatise of Human Nature (Hume 1978)
}




\title{
Stephen Engstrom
}

Kant

\author{
Anth Anthropology from a Pragmatic Point of View \\ $G \quad$ Groundwork for the Metaphysics of Morals \\ KrV Critique of Pure Reason \\ L [Jäsche] Logic \\ MS Metaphysics of Morals
}

References to Kant's works cite the volume and page of Kant 1902-, except in the case of references to the Critique of Pure Reason, which employ the pagination of the first (A) and second (B) editions. Translations are my own.

\section{Notes}

${ }^{\mathrm{i}}$ Ethics 103 (1993): 436-57; reprinted in Baier 1994: 268-93.

ii See T III.iii.6.619-20. The views ascribed to Baier in this paragraph and the next can for the most part be found in Baier 1994: 268, 290.

iii In encouraging Humeans to mock her Humean mockery of Kantian morality, Baier allows, in effect, that her own mockery may not, in the end, be entirely able to bear its own survey. As I noted, Baier acknowledges that 'the true Humean must somehow learn to mock gently', conceding that she may have 'mocked the Kantian position a bit too unmercifully'. Possibly this was brought home to her by her encounter with an undergraduate student at the University of Southern California, who, as she describes in her essay's Postscript, approached her after her presentation of the paper, visibly upset by what he perceived as her attack on Kant.

iv For reasons I will touch on at the conclusion of this paper, I do not share Baier's interpretation of Kant's ethics as a morality of guilt, even though, as she notes, such an interpretation may seem to be suggested by things Kant says in certain places, for instance in his account of conscience.

v E.g., Bernard Williams in 'Internal and External Reasons' (Williams 1981).

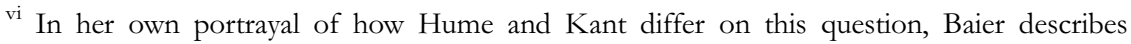
Hume's position as follows: 'Agreeing with the rationalists that when we use our reason we all appeal to universal rules ... and failing to find any such universal rules of morality, as well as failing to see how, even if we found them, they should be able, alone, to motivate us to act as they tell us to act, he claims that morality rests ultimately on sentiment' ('Hume, the Women's Moral Theorist?', Baier 1994: 56). Although Baier seems to endorse this view, she allows that the 'moral ideals of equality and freedom' expounded in Kant's texts are 'inspiring', seeming thereby at least implicitly to acknowledge that they have a motivating power ('Moralism and Cruelty', Baier 1994: 290). As Kant understands such ideals, however, they could have their 


\section{Reflection and Reason in Hume and Kant}

source only in reason, in that, according to his Platonic understanding of them, no experience could provide an instance perfectly adequate to them. Such ideals do not seem easily accommodated by Hume's empiricist epistemology. Baier says that a certain sort of freedom namely 'freedom of thought and expression', which is not to be confused with autonomy - ' is an ideal' for Hume ('Hume, the Women's Moral Theorist?', Baier 1994: 63), but she does not explore how such an ideal is to be squared with Hume's empiricist commitments.

vii 'The Need for More than Justice' (Baier 1994: 26).

viii The awareness is of course merely implicit, indeed occluded, in that a certain self-deception is involved. Cognizant of the commonly accepted idea that the recognition of what is right and what is good has an efficacious power in human thought, discourse, and action, the cruel moralizer puts this idea to a fallacious and self-deceptive use, resorting to other-than-rational forms of efficacy (in bluster, intimidation, punishment, etc.), through which his distorted representations of what is right and what is good may acquire the trappings of cognitive validity and authority.

ix The views attributed to Baier in this paragraph are drawn mainly from 'Hume, the Reflective Women's Epistemologist?' (Baier 1994: 76-94). The interpretation of Hume's Treatise referred to in the final sentence is set out in Baier 1991; see esp. chaps. 4 and 12. The claim that Hume sees reflection as providing the test for authority (or normativity) has been advanced by others as well, perhaps most prominently by Christine Korsgaard (1996: 51-66). Like Korsgaard, Baier employs the slogan 'normativity as reflexivity' to express the idea.

${ }^{x}$ Of course, Hume is aware of attempts on the part of Descartes and other philosophers to gain knowledge of the nature of the mind by meditating on the activity of thinking. When Baier says that Hume 'generalizes' the reflective operation, the special operation of reflection to which she implicitly alludes by way of contrast seems clearly to be that of the Cartesian cogito, which Leibniz too has in mind when speaking of reflection. Hume rejects the approach followed by such rational psychologists, citing as a principal reason for his methodological reform his conviction that 'the essence of the mind' is 'equally unknown to us with that of external bodies' ( $T$ xvii). But Kant too is a famous critic of rational psychology. When Hume opts to found his science on experience rather than on rational intuition, he leaves unconsidered an alternative approach, intermediate between these extremes, which confines itself to reflection on reason's self-conscious activity. This alternative will be considered more closely below.

${ }^{x i}$ Hume introduces this principle as an empirical proposition, adducing, in accordance with his experimental method, various phenomena in support of it (T I.i.1.4-7); yet in his subsequent elaboration of his science of human nature it takes on the aspect of a fixed requirement, playing a role similar to that of an a priori regulative principle, as if it were integral to the method or a kind of projection of it onto the object it is being used to investigate.

xii See $L \oint \S 5-6,9: 93-95$; cf. Anth 7:134n, 141. Just as Hume's experimental method entails, as we noted, a neglect of the identical activity of consciousness that constitutes the subject, so it entails a neglect of the identity of the act of representing that constitutes a concept. Hume accordingly holds, with Berkeley, that all ideas are 'particular in their nature', and 


\section{Stephen Engstrom}

to explain how an idea can be general in representation he assigns to custom a role in the use of a linguistic term to which the idea has been annexed (Treatise I.i.7). From this explanation it is but a short step to the consequence that all reasoning and even intuition rest on custom.

xiii A main reason why it is important not to overlook the immediacy of self-consciousness is that only by appreciating it can we comprehend how it is that we understand from the start (a priori) that unity is constitutive of all thought and knowledge. I describe the relation between self-consciousness and unity in Engstrom 2013.

xiv Thus Hume includes as a chief rule for judging of causes and effects the principle that 'The same cause always produces the same effect, and the same effect never arises but from the same cause', even though, because his experimental method prevents him from reflecting on self-consciousness and its immediacy, he has no option but to suppose, as he does, that 'This principle we derive from experience' ( $T$ I.iii.15.173). And he also holds that 'all sound judgement of truth and falsehood' 'should be the same to every rational intelligent being' (ECPM I.170).

xv Only relative to its use under special conditions could there be any such conflict. If, for instance, by 'pure reason' we understand theoretical reason in a speculative use (i.e., beyond the limits of possible experience), then there is a sense in which the answer can be 'no', in that, so far as reason in such use allows itself to be influenced by a certain illusion and so fails to heed its own implicit recognition that discursive knowledge is possible only under sensible conditions, it can fall into conflict with itself; Kant describes reason in such use as in itself dialectical' (KrV A777/B805). But when we set such misuse under special conditions to the side and consider reason itself, we must say, as Kant does, that it 'cannot possibly itself contain original deceptions and illusions' ( $K r V$ A669/B697). Hume is blocked from this insight by his decision to follow the experimental method, which, as was noted earlier, prevents him from securing an understanding of reason on which reason is not from the start conceived as 'fallible and uncertain'.

${ }^{\text {xvi }}$ Notwithstanding the fact, noted by Baier, that Kant speaks of conscience as an inner court. According to its very idea, ethical motivation cannot lie in fear of any kind of punishment. xvii 'If you insult him, you insult yourself; if you steal from him, you steal from yourself' (MS 6:332). The principle of equality is nothing but the right to restore the original equality through the negation of its negation. Kant's description of retorsio iocosa makes explicit that the mockery is returned 'in equal measure' (gleichmäßig) (MS 6:467; cf. 232-33). Mockery that failed to respect the measure of equality would be unmerciful.

xviii This paper was presented, in earlier versions, at a memorial session for Annette Baier, held during the 2013 Meeting of the Eastern Division of the American Philosophical Association, and at a meeting of the Chicago-Area Consortium in German Philosophy. I thank the organizers of these events and the other participants for stimulating discussion and am particularly grateful to Lilli Alanen for a number of helpful suggestions. I also want to register my gratitude to Annette Baier herself for her warmth, humanity, and generous friendship. I dedicate this paper to her memory. 


\section{Bibliography}

Baier, A. C. (1991), A Progress of Sentiments. Cambridge: Harvard University Press.

Baier, A. C. (1994), Moral Prejudices. Cambridge: Harvard University Press.

Engstrom, S. (2013), 'Unity of Apperception', Studi Kantiani 26: 37-54.

Hume, D. (1975), Enquiries Concerning Human Understanding and Concerning the Principles of Morals, ed. L. A. Selby-Bigge and P. H. Nidditch. Oxford: Clarendon Press.

Hume, D. (1978), A Treatise of Human Nature, ed. L. A. Selby-Bigge and P. H. Nidditch. Oxford: Clarendon Press.

Kant, I. (1902-), Kants gesammelte Schriften, herausgegeben von der Deutschen (formerly Königlich Preußischen) Akademie der Wissenschaften, 29 vols. Berlin: Walter de Gruyter (and predecessors).

Korsgaard, C. M. (1996), The Sources of Normativity. Cambridge: Cambridge University Press.

Williams, B. (1981), Moral Luck. Cambridge: Cambridge University Press. 